
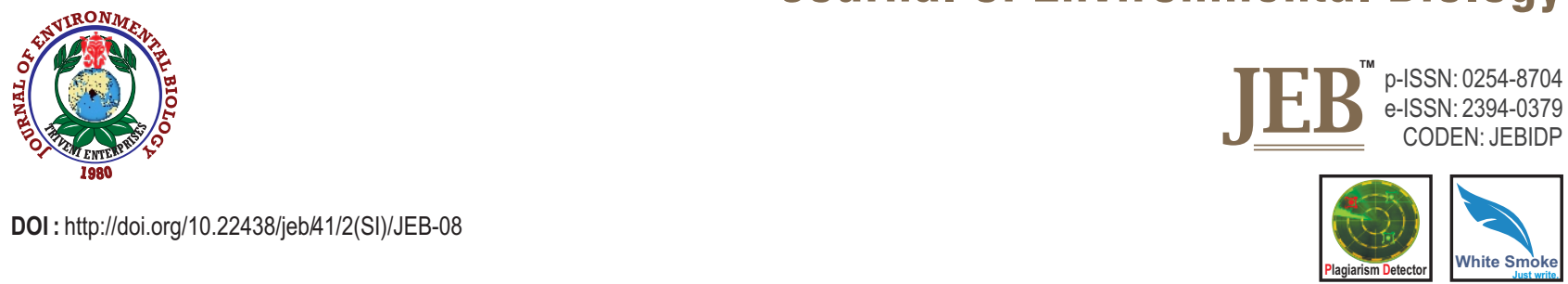

\title{
Species composition of dry-temperate forest as an important habitat for wildlife fauna species
}

\author{
M.N. Rajpar ${ }^{1}$, M. Ozturk ${ }^{2 *}$, V. Altay ${ }^{3}$, S. Ullah ${ }^{1}$, A. Ullah ${ }^{4}$, C.O. Martin ${ }^{5}$, S. Gücel ${ }^{6}$ and M. Zakaria ${ }^{5}$ \\ ${ }^{1}$ Department of Forestry, Shaheed Benazir Bhutto University Sheringal Dir (Upper), Khyber Pakhtunkhwa, 18000, Pakistan \\ ${ }^{2}$ Center for Environmental Studies, Ege University, 35100 Bornova-Izmir, 35040, Turkey \\ ${ }^{3}$ Biology Dept., Faculty of Science and Arts, Hatay Mustafa Kemal University, Hatay, 31030, Turkey \\ ${ }^{4}$ Department of Agricultural Extension Education and Communication, The University of Agriculture, Peshawar, 25000, Pakistan \\ ${ }^{5}$ Faculty of Forestry, Universiti Putra Malaysia, Serdang, Selangor, 43400, Malaysia \\ ${ }^{6}$ Near East University, Environmental Research Center, Nicosia, 99138, Northern Cyprus \\ *Corresponding Author Email : munirozturk@gmail.com
}

Paper received: 18.04 .2019

Revised received: 21.09 .2019

Accepted: 03.01. 2020

\begin{abstract}
Aim: To determine the present species composition and diversity in dry temperate forest ecosystem, especially trees, shrubs, ground cover, birds, reptiles and mammals.

Methodology: The vegetation composition and diversity of dry-temperate forest in Kumrat valley was determined through employing the $20 \times 20 \mathrm{~m}$ ( 0.4 ha) quadrant method. In addition, fauna species were detected through direct visual observations. A total of 100 quadrant plots were randomly selected to determine the vegetation composition and diversity from July, 2017 to August, 2018.
\end{abstract}

Results: A total of 7 tree species, 3 shrubs, and 12 grass species were identified, which were attracted into the study area. The highest tree density was determined for $P$. wallichiana $\left(3.375\right.$ tree ha $\left.{ }^{-1}\right)$ and the lowest one for $J$. regia $\left(0.300\right.$ tree ha $\left.{ }^{-1}\right)$. CAP tests indicated that the diversity indices, i.e., ShannonWinner's Diversity Index $\left(H_{1}=2.908+0.161\right)$, Margalef's Richness Index $\left(R_{1}=3.26+0.112\right)$ and McIntosh Evenness Index $(E=0.9746+0.0206)$ occured in Kumrat valley. Further, diversity indices of trees varied from species to species, e.g., the highest tree species diversity $\left(H_{1}=2.248\right)$ and species richness $\left(\mathrm{R}_{1}=2.730\right)$ was recorded in Picea smithiana and the lowest one $\left(H_{1}=0.297\right)$ and richness $\left(R_{1}=0.4024\right)$ in Juglans regia. Taxus baccata ( $\mathrm{E}=0.9763$ ) showed even distribution in the study area as compared to other tree species. The direct observation observed a total of 11 mammal species (6 endangered, 3 data deficient, and 2 species least concern), 41 bird species (mostly least concern), and 6 reptile species (4 least concern, one data deficient, and one vulnerable) simultaneously within the same area where plant cover was determined.

Interpretation: The results of this study demonstrated that plant cover structure and composition of dry-temperate forest is the most prominent factor that had formed a wide array of different habitats to attract the higher diversity of fauna.

Key words : Birds, Food resources, Mammals, Reptiles, Species diversity

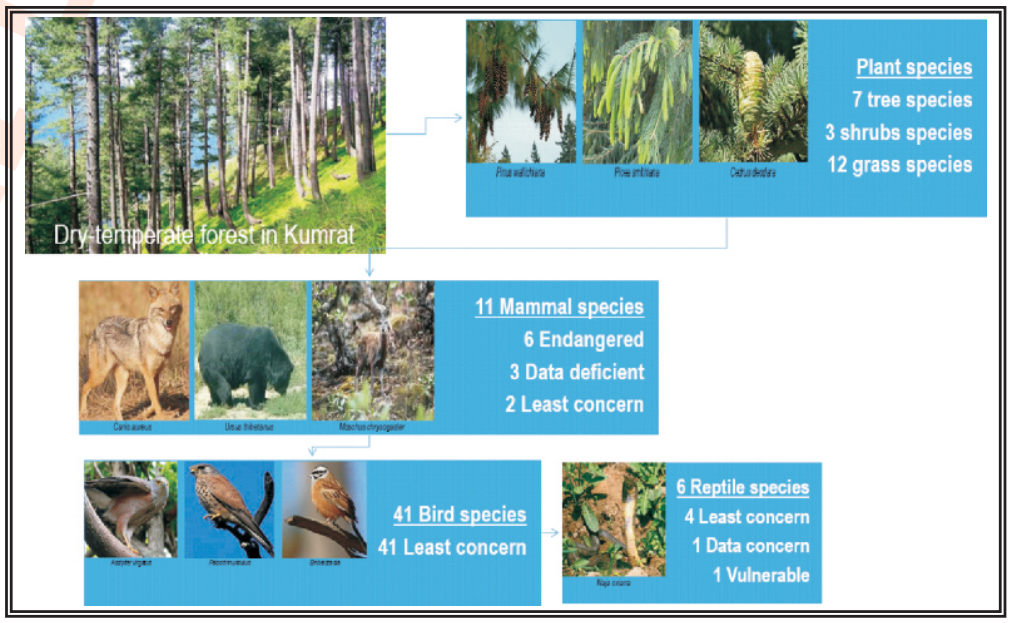

How to cite : Rajpar, M.N., M. Ozturk, V. Altay, S. Ullah, A. Ullah, C.O. Martin, S. Gücel and M. Zakaria: Species composition of dry-temperate forest as an important habitat for wild life fauna species. J. Environ. Biol., 41, 328-336 (2020). 


\section{Introduction}

Determining the plant cover structure and diversity is an essential tool to gather information about the habitat suitability and extent of disturbance, recovery process, and management activities. In addition, plant diversity also indicates the current status of the forest ecosystem health, disturbance and productivity (Onaindia et al., 2004; Ahmad et al., 2015), which are the essential factors attracting the wildlife fauna species to inhabit, forage, rest and breed.

Plant cover composition and diversity is the most prominent component of the dry-temperate forest ecosystem and it has been considered as an important habitat for a wide array of wildlife fauna species. The flora of dry-temperate forest may vary from area to area, depending upon site quality, aspect, slope, microclimate, topography, and anthropogenic interference. The variation among the species composition and structure establishes heterogeneous habitats characterized by spatial variability in layers and rich in food resources, which harbor higher diversity of wildlife species that directly or indirectly are dependent on plant cover structure and composition for their survival (Frickle et al., 2013; Douglas et al., 2014). Wildlife fauna species are habitat specialists and show close associations with plant diversity and richness. Which could be due to the fact that habitat diversity offers a variety of food resources, safe breeding sites, suitable loafing grounds, and shelter from predators and harsh weather (Attua and Pabi, 2013; Rajpar and Zakaria, 2014; Rajpar, 2018).

The dry-temperate forest is bestowed with a diversity of plant species composition, such as; trees, shrubs, grasses, herbs, etc. This diversity and structure varies from area to area, i.e., dense patches, fragments, remnants and scattered trees. The difference in the plant cover thickness, compactness, distribution, and heterogeneity form different layers attracting mammals, birds and reptiles. Wild life fauna are integral part of the dry-temperate forest ecosystem as they play a crucial role in forest ecosystem health and management, e.g., gene dispersal, food chain, food web, prevent population expansion of pests, disperse seed, control the grasses, pollinate the flowers, increase the fruit production, and balance nutrients in the soil (Greenberg and Walter, 2010; Carlo et al., 2013; Bauer and Hoye, 2014). They also serve as bio-indicators of forest ecosystem by indicating productivity and environmental condition (Roemer et al., 2009; Dawson and Efford, 2009).

There are eleven types of forest habitats in Pakistan and these vary in the structure and composition, as well as food resources which attract 757 birds, 174 mammals and 195 reptile species (Wilson and Reeder, 2005). Unfortunately, these forested habitats are being lost and degraded because of human intervention (DeFries et al., 2005; Wright, 2005; Clark et al., 2009; Edwards et al., 2011), such as; alteration in land use patterns (Fitzeherbertet al., 2008; Sodhi et al., 2010; Miettinen et al., 2011), deforestation for agricultural conversion, human settlements, cattle ranches, illegal logging for timber and fuel wood collection, and fire (Cristobal-Azkarate and Arroyo-Rodriguez, 2007; Irwin, 2008; Gonzalez-Zamora et al., 2009). The land use change is the major driving factor altering the plant cover structure and composition (Maas et al., 2009) as well as productivity, i.e., food resources (Chaves et al., 2012; Höbinger et al., 2012) which ultimately lead towards habitat fragmentation, scarcity of food resources, and effects the distribution and population parameters of wildlife fauna species (Mayaux et al., 2005).

Notably, monitoring the structure and composition of plant cover together with faunal diversity is highly essential, because it helps in tracking the changes in plant species structure and composition, and fluctuation in faunal diversity (Rajpar et al., 2017; Rajpar, 2018) and richness during a specific period. No detailed study has been carried out till now to quantify the species composition and diversity as a prominent component of the drytemperate forest ecosystem allowing it to serve as an ideal habitat for a wide array of faunal species. In light of the above, the aim of this study was been to determine the plant species composition and diversity of dry-temperate forest of Kumrat valley so as to understand their effects on the diversity of wildlife fauna species.

\section{Materials and Methods}

Study Area: Study was carried out in a dry-temperate forest in Kumrat valley, Dir Upper District, Khyber Pakhtoonkhwa Pakistan (Fig. 1). Kumrat valley lies between 2211-2454 m above sea level at $35^{\circ} 32^{\prime} 11^{\prime \prime} \mathrm{N}$ latitude and $75^{\circ} 13^{\prime} 45^{\prime \prime} \mathrm{E}$ longitude, covering an area of 41,840 ha as forest. The topography of the valley is rough with the mountains located at the foothills of Hindukush mountain range and surrounded by Chitral (North), Kalam (East), Ayun Valley (West) and Lower Dir (South). It is full of evergreen pastures, snow-clad mountains. The flora is comprised of Abies pindrow, Picea smithiana, Cedrus deodara, Pinus wallichiana, which frequently grow on hill ridges associated with evergreen broad leaf tree species namely; Quercus ilex, Q. dilatata, $Q$. semecarpifolia, Betula utilis and few others. A prolific shrubby vegetation covers the ground as an undergrowth and is composed of Viburnum nervosum, Berberis lyceum and the species of Salix, Lonicera and Ephedra.

The climatic conditions are moderately cool in summer with $20-25^{\circ} \mathrm{C}$ temperatures, but in winters it ranges between $4-10$ ${ }^{\circ} \mathrm{C}$. The mean annual precipitation lies between $100-255 \mathrm{~mm}$ and most of it falls during winter in the form of snow, with good infiltration into the soil.

Plant species survey: The species composition of trees, shrubs (Mumby et al., 1997; Hudon, 1997; Fernandez-Alaez et al., 2002; Hassen-Aboushiba et al., 2013) and grasses was investigated for their structure by employing "Quadrat method" (20x20 m) in different habitats. In all 20x20 m (0.04 ha) 100 quadrats were sampled randomly to record the plant diversity from July to August 2017. The location of each sampling plot was recorded with the help of GPS for an easy relocation. In each quadrat ground cover 


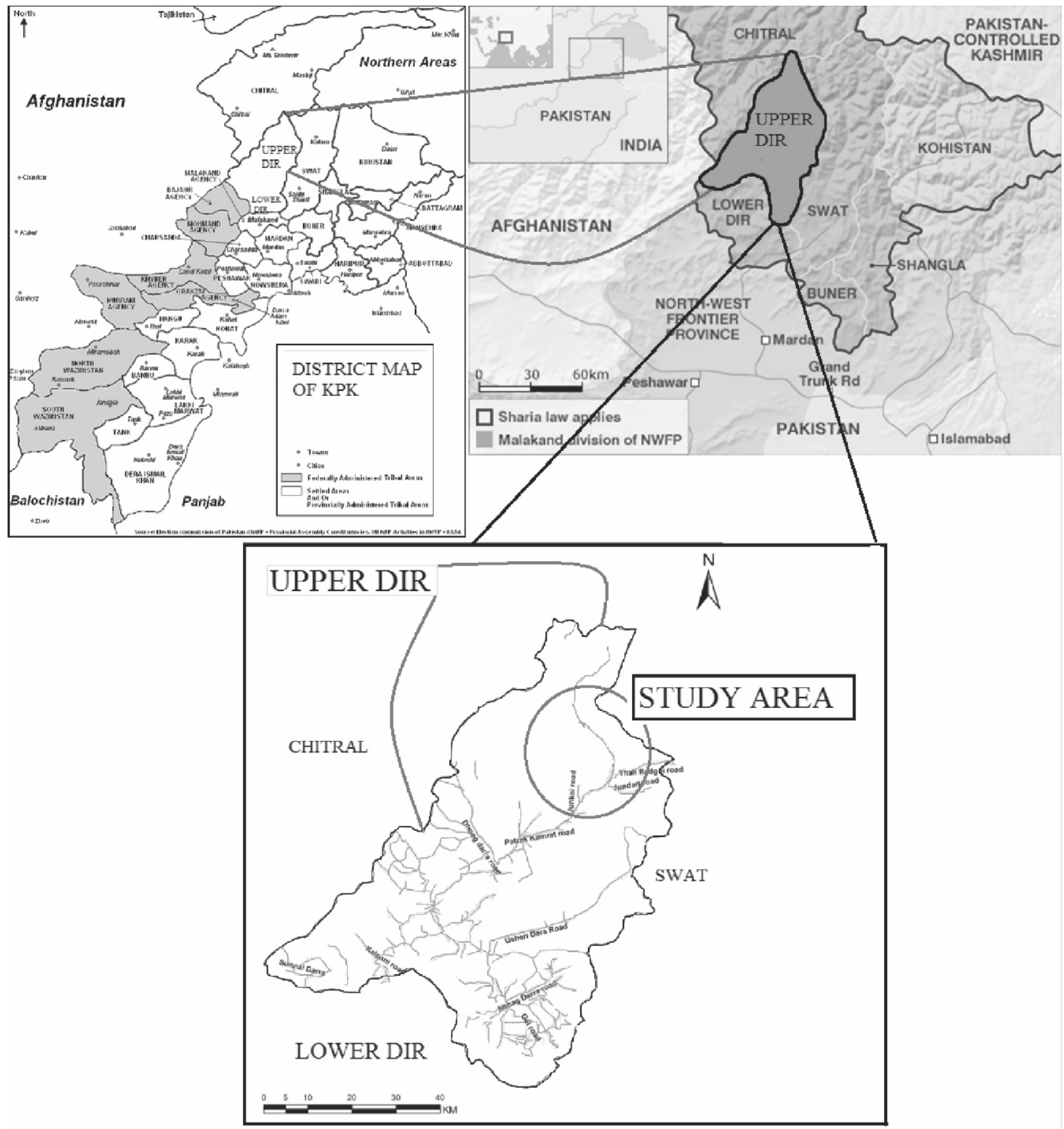

Fig. 1 : Location map of the study area.

(\%) and number of tree species, wood or shrub and grasses were noted. The methodology was same as followed by Sharma et al. (2016) and Fernandez-Alaez et al. (2002).

Fauna Survey: Fauna species were surveyed every month at different locations simultaneously at the same locations with factors like plant cover structure and composition from $0800 \mathrm{hrs}$ to $1200 \mathrm{hrs}$ in each month. Multiple visits were made to survey fauna species throughout the study period. The methodology was followed as described by Kunz et al. (2007), Boldreghini and Dall'Alpi (2008) and Hamel et al. (2009).

\section{Data Analysis}

Tree Density: The tree density were calculated following the methods outlined by Baboo et al. (2017), Karki et al. (2017), and 
Vibhuti and Bargali (2018). It is the simple number of trees per ha. The tree density was measured using $20 \times 20 \mathrm{~m}$ quadrant plot $=$ $400 \mathrm{~m}^{2}$ or 0.4 ha. We determine the 100 sample plots for vegetation density ha ${ }^{-1}$.

Tree Density $=$ Sample area $x$ total sample plot $=40$ ha

Tree Density $=$ Total number of detected tree individuals $/$ total sample plot area(ha)

Diversity indices : The diversity indices of plant cover were analyzed using Community Analysis Package (PCA) Version 4.0 according to Henderson and Seaby (2007). Shannon's diversity index, Margalef's Richness Index and McIntosh's Evenness index were used to determine the diversity indices of plant cover.

Species diversity: It is an index that incorporates the number of plants in an area and also takes into account their relative abundance and provides more information about plant cover composition, such as (Hassen-Aboushiba et al., 2013), rarity and commonness of trees, shrubs, grasses and herbs in a particular area .

\section{Shannon's Diversity Index:}

$$
H^{\prime}=-\sum_{i=1}^{s} p_{i} \ln p_{i}
$$

where, $\mathrm{H}^{\prime}$ designates diversity, $\mathrm{S}$ indicates the number of species, $i$ specifies the abundance of species, $N$ relates to the total number of all individuals and $p_{i}$ is the relative abundance of each species.

Species richness: It is the number of different plant species in a given area. It also provides information on homogeneity and rarity of plant cover structure.

\section{Margalef's richness index:}

$$
(\mathrm{R})=\mathrm{S}-1 / \ln (\mathrm{n}):
$$

where, $S=\Sigma$ species in the plot and $n=\Sigma$ Individuals of all species (Hassen-Aboushiba et al., 2013).

Species evenness: It is a measure of the relative abundance of different plant species in a particular area. McIntosh's Index:

$$
D=-\frac{N-N}{N-\sqrt{N}}
$$

where, $N$ is the total number of individuals in the sample and $U$ is given by the expression:

$$
U=\sqrt{ } \Sigma n_{i}^{2}
$$

where, $n$ (i) is the number of individuals in the $i^{\text {th }}$ species and the summation is undertaken over all the species, $U$ is the Euclidean distance of the community from the origin (Henderson and Seaby, 2007).

\section{Results and Discussion}

Species composition: Seven evergreen and broad leaved tree species occured in Kumrat valley. Out of these seven species, five were coniferous and two broadleaved. Pinus wallichiana was the most dominant tree species $(39.82 \%)$ and Juglans regia the rarest tree species $(3.54 \%)$. Few shrub species were also documented in the area, however, species composition varied from area to area depending on the altitude, hilly terrain and bottom of valleys (Table 1).

Tree density: The highest tree density was determined for $P$. wallichiana (3.375 tree ha $\left.{ }^{-1}\right)$ and the lowest one for J. regia $(0.300$ tree ha $\left.^{-1}\right)$ (Table 1).

Tree species diversity: Community Analysis Package (CAP; Version 4.0) test results indicated that overall tree diversity of drytemperate forest was Shannon-Winner's Diversity Index; $\mathrm{H}_{1}=2.908 \pm 0.161$, however the tree diversity varied from species to species, e.g., the highest tree diversity was recorded in Picea smithiana $\left(\mathrm{H}_{1}=2.248\right)$ and the lowest in Juglans regia $\left(\mathrm{H}_{1}=0.297\right)$ (Table 1).

Tree species richness: The results of Margalef's Richness Index $\left(R_{1}\right)$ states that species richness of trees may vary depending upon edaphic and site quality. In the study area, the highest species richness was recorded in Picea smithiana $\left(R_{1}=2.730\right)$ and the lowest in Juglans regia $\left(R_{1}=0.4024\right)$. However, it was concluded that overall tree species richness of Kumrat valley was $\mathrm{R}_{1}=3.26 \pm 0.112$ (Table 1).

Tree species evenness: Mclntosh Evenness Index indicated that tree species evenness of Kumrat valley was around $\mathrm{E}=0.9746 \pm 0.0206$. Taxus baccata $(\mathrm{E}=0.9763)$ was evenly distributed in the area as compared to other tree species (Table 1).

Mammal species composition: Eleven mammal species were sampled in the valley during the study period. Out of 11 species, 6 species were endangered, 3 species data deficient, and the rest two species were of least concern. These findings indicated that the valley forms a suitable habitat for them (Table 2).

Bird species composition: Kumrat valley occurs at higher altitude above sea level full of pine and broadleaved species, falling in the dry-temperate forest of Pakistan. A total of 41 bird species belonging to 22 families were noted through direct observation. These included eagles, kites, tits, tree creepers, doves, crows, treepies, jays, drongos, buntings, finches, shrikes, swallows, thrushs, flycatchers, wagtails, pheasants, quails and few others. The higher number of bird species indicates that this valley is rich in plant cover as well as food resources, which attract a wide variety of bird species (Table 3 ).

Reptile species composition: A total of six reptile species were detected which included agama, lizards, snake, and skink. The 


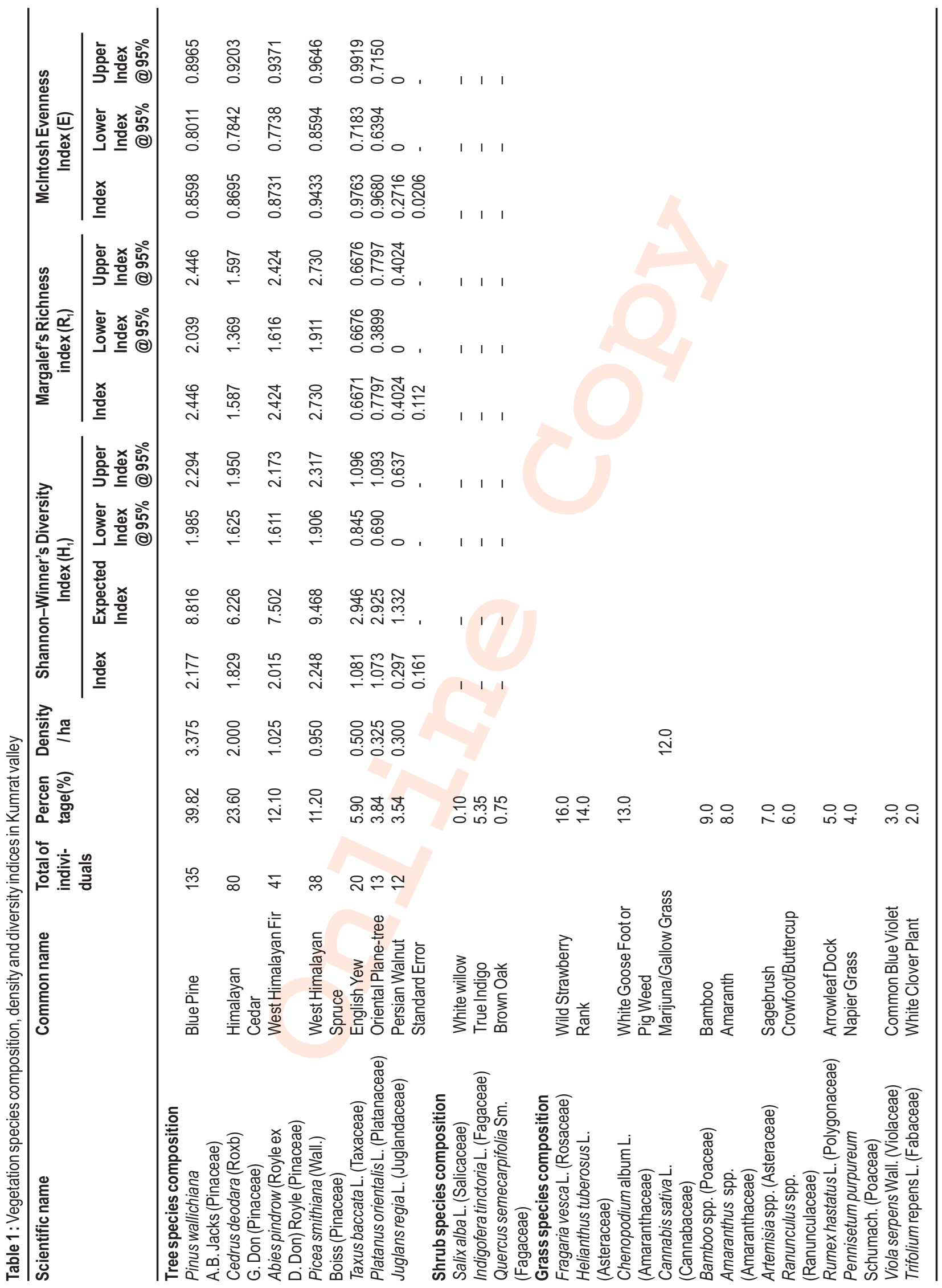

- Journal of Environmental Biology, Special issue, March 2020 
Table 2 : List of mammal species found in Kumrat Valley

\begin{tabular}{llll}
\hline Family & Scientific Name & Common Name & Status \\
\hline Bovidae & CaprafalconeriWagner. & Kashmir Markhor & Endangered \\
& Capra ibex sibirica Pallas. & Himalayan Ibex & Endangered \\
Canidae & Canis lupus Linnaeus. & Indian Wolf & Endangered \\
& Vulpes vulpes Linnaeus. & Red Fox & Data Deficient \\
& Canis aureus Linnaeus. & Jackal & Least Concern \\
Ceropithecidae & Macaca mulatta Zimmermann. & Rhesus Monkey & Least Concern \\
Felidae & Lynx lynx Linnaeus. & Eurasian Lynx & Endangered \\
Moschidae & Moschus chrysogasterHodgson. & Himalayan Musk Deer & Endangered \\
Mustelidae & Martes flavigulaBoddaert. & Yellow-throated Martin & Data Deficient \\
Sciuridae & Eupetaurus cinereus Thomas. & Woolly Flying Squirrel & Data Deficient \\
Ursidae & Ursusthibetanus G. Curvier. & Asiatic Black Bear & Endangered \\
\hline
\end{tabular}

fewer numbers of reptiles could be due to the fact that this valley is falling under cold weather condition, e.g., winter has severe snow fall. Reptiles are cold vertebrates and cannot maintain their body temperatures. The species recorded by us were detected near human settlements and within the agriculture fields, especially during summer season (Table 4).

Determining the plant species composition and food resources is an important tool to examine the habitat suitability and productivity of a forest ecosystem; reason being plant cover structure, composition, and diversity plays a crucial role to attract a diversity of faunal species, such as; mammals, birds and reptiles. This information would help to understand how to enhance the population of endangered species.

Our results on the plant cover has shown that Kumrat valley has diverse topography; hilly terrain, snow covered peaks, pastures, riparian habitats, and mixed plant cover (conifer and broadleaved evergreen plant species). These diverse habitats harbor different herbivorous mammal species (C. falconeri, $M$. chrysogaster and $C$. ibex sibirica) and carnivorous mammal species, such as; C. lupus, U. thibetanus, L. lynx and $V$. vulpes. Recording sufficient number of endangered mammal species clearly shows that this valley is ideal habitat for them (Khan et al., 2016). However, it was found that habitat preference among the mammal species varies depending on the habitat requirement, foraging behaviour and anthropogenic disturbances (Bagchi et al., 2003; Nagmail, 2006; Phillips et al., 2006; Ashraf et al., 2014).

The existence of a wide array of bird species indicates that the valley is ideal and productive habitat for them. It offers a good shelter for a wide range of species for distribution, plenty of food resources, safe breeding and foraging grounds, as well as, protecting them from severe weather conditions. The other reason being, dry-temperate forest is encompassed of heterogeneous habitats, i.e., dense patches of trees, thick and dense fragments of shrubs, and variety of pastures. Alpine pastures dominated by variety of grasses and shrubs offers suitable foraging sites, and shelter from predators for $L$. impejanus, L. lerwa, T. himalayensis, A. chukar, P. macrolopha, L. leucomelanos and C. coturnix. These bird species are opportunistic and adaptive in foraging and habitat preference ( $\mathrm{Li}$ et al., 2010). They often select pine dominated habitats, mostly cliff areas having pine trees and tall grasses (lamsiri and Gale, 2008). The pheasants often prefer evergreen mix pine and broadleaved forests with more than one meter tall shrub layers (lamsiri, 2008). The habitat preference can be attributed to the occurrence of food resources like seeds of grasses, roots, insects, fruits and wild nuts (Li et al., 2010). Similarly, chukar (A. chukar) and partridges (L. lerwa) often prefer permanent areas with dense grass cover for foraging and breeding purposes, reason being grasses produce a variety of grains forming primary diet for them and also provide protection in breeding and around chick rearing grounds. The grassy areas offer good shelter from predators and harsh weather (Homan et al., 2000; Leif, 2005).

Likewise, A. chrysaetos, A. virgatus, $E$. caeruleus, $F$. tinnunculus and $A$. badius have curved beak and claws, superb eyesight and powerful wings (Parejo et al., 2001; Serrano et al., 2001; Balbontin et al., 2008). They are vagrant species (often keep changing their habitats) and carnivorous in nature, mostly preying on variety of animals, rats, mice, ground squirrels, passerine birds and reptiles. It was observed that raptors differ in habitat selection e.g., eagle preferred forested habitats, besra and shikra utilized scrublands, and kites agricultural fields and foraging ecology, golden eagle search food from a perch, besra and kestrel search food while on flight, and black-winged shoulder kite through hovering (Martin and Piersma, 2009; Martin and Portugal, 2011; O'Rourke et al., 2010; Potier et al., 2016). Similarly, it was observed that $P$. leucogenys, $P$. leucotis and $P$. cafer bulbuls often concentrated around the fruit trees, shrubs, agricultural fields, parks and grassy lawns, foraging on fresh fruits (berries), grains, and arboreal insects. It was also observed that buntings were closely linked with arable fields and patches of shrublands to forage on invertebrates, especially insects (Kosinski and Tryjanowski, 2000; Mason and Macdonald, 2000; Donald et al., 2001; Dale and Manceau, 2003; Menz et al., 2009). 
Table 3 : List of the bird species recorded in Kumrat valley

\begin{tabular}{|c|c|c|c|}
\hline Family & Scientific name & Common name & Current status \\
\hline Accipitridae & $\begin{array}{l}\text { Aquila chrysaetos Linnaeus. } \\
\text { Accipiter virgatus Temminck. } \\
\text { Elanus caeruleus Desfontaines. } \\
\text { Accipiter badius Gmelin. }\end{array}$ & $\begin{array}{l}\text { Golden Eagle } \\
\text { Besra } \\
\text { Black-shouldered Kite } \\
\text { Shikra }\end{array}$ & $\begin{array}{l}\text { Least Concern } \\
\text { Least Concern } \\
\text { Least Concern } \\
\text { Least Concern }\end{array}$ \\
\hline Aegithalidae & Aegithalos concinnus Gould. & Black-throated Tit & Least Concern \\
\hline Certhiidae & Certhia himalayana Vigors. & Ber-tailed Treecreeper & Least Concern \\
\hline Columbidae & Streptopelia decaocto Frivaldszky. & Eurasian Collared Dove & Least Concern \\
\hline Coridae & Zenaida macroura Linneus. & Mourning Dove & Least Concern \\
\hline Corvidae & $\begin{array}{l}\text { Corvus macrorhynchos Wagler. } \\
\text { Dendrocitta vagabunda Latham. } \\
\text { Garrulus lanceolatus Vigors. }\end{array}$ & $\begin{array}{l}\text { Large-billed Crow } \\
\text { Rufous Treepie } \\
\text { Black-headed Jay }\end{array}$ & $\begin{array}{l}\text { Least Concern } \\
\text { Least Concern } \\
\text { Least Concern }\end{array}$ \\
\hline Dicruridae & Dicrurus macrocercus Vieillot. & Black Drongo & Least Concern \\
\hline Emberizidae & $\begin{array}{l}\text { Emberiza leucocephalos S.G. Gmellin. } \\
\text { Emberiza cia Linnaeus. }\end{array}$ & $\begin{array}{l}\text { Pine Bunting } \\
\text { Rock Bunting }\end{array}$ & $\begin{array}{l}\text { Least Concern } \\
\text { Least Concern }\end{array}$ \\
\hline Falconidae & Falco tinnunculus Linnaeus. & Common Kestrel & Least Concern \\
\hline Fringillidae & Carpodacus erythrinus Pallas. & Common Rosefinch & Least Concern \\
\hline Hirundinidae & Hirundo rustica Linnaeus. & Common Swallow & Least Concern \\
\hline Laniidae & $\begin{array}{l}\text { Lanius tephronotus Vigors. } \\
\text { Lanius vittatus Valenciennes. }\end{array}$ & $\begin{array}{l}\text { Grey-backed Shrike } \\
\text { Bay-backed Shrike }\end{array}$ & $\begin{array}{l}\text { Least Concern } \\
\text { Least Concern }\end{array}$ \\
\hline Leiothrichidae & Trochalopteron lineatum Vigors. & Streaked Laughing Thrush & Least Concern \\
\hline Meropidae & Merops orientalis Latham. & Green Bee-eater & Least Concern \\
\hline Monarchidae & Terpsiphone paradise Linnaeus. & Asian Paradise Flycatcher & Least Concern \\
\hline \multirow[t]{4}{*}{ Motacillidae } & Motacilla maderaspatensis Gmelin. & White-browed Wagtail & Least Concern \\
\hline & Motacilla flava Linnaeus. & Western Yellow Wagtail & Least Concern \\
\hline & Motacilla alba Linnaeus. & White Wagtail & Least Concern \\
\hline & Motacilla cinerea Tunstall. & Grey Wagtail & Least Concern \\
\hline \multirow[t]{2}{*}{ Muscicapidae } & Myophonus caeruleus Scopoli. & Blue Whistling Thrush & Least Concern \\
\hline & Saxicola caprata Linnaeus. & Pied Bushchat & Least Concern \\
\hline Paridae & Parus majorLinnaeus. & Great Tit & Least Concern \\
\hline \multirow[t]{7}{*}{ Phasianidae } & Lophophorus impejanus Latham. & Himalayan Monal Pheasant & Least Concern \\
\hline & Lerwa lerwa Hodgson. & Snow Partridge & Least Concern \\
\hline & Tertraogallus himalayensis G.R. Gray. & Himalayan Snowcock & Least Concern \\
\hline & Alectoris chukar Gray. & Chukar & Least Concern \\
\hline & Pucrasia macrolopha Lesson. & Koklass Pheasant & Least Concern \\
\hline & Lophura leucomelanos Latham. & Khalig Pheasant & Least Concern \\
\hline & Coturnix coturnix Linnaeus. & Common Quail & Least Concern \\
\hline Phylloscopidae & Phylloscopus collybita Vieillot. & Brown Chiffchaff & Least Concern \\
\hline \multirow[t]{3}{*}{ Pycnonotidae } & Pycnonotus cafer Linnaeus. & Red-vented Bulbul & Least Concern \\
\hline & Pycnonotus leucotis Gould. & White-eared Bulbul & Least Concern \\
\hline & Pycnonotus leucogenys Gray J.E. & Himalayan Bulbul & Least Concern \\
\hline Sturnidae & Acridotheres tristis Linnaeus. & Common Myna & Least Concern \\
\hline
\end{tabular}

Table 4 : List of reptile species recorded in Kumrat valley

\begin{tabular}{llll}
\hline Family & Scientific name & Common name & Current status \\
\hline Agamidae & Paralaudakia himalayana Steindachner. & Himalayan Agama & Least Concern \\
& Calotes versicolorDaudin. & Oriental Garden Lizard & Least Concern \\
& Laudakia tuberculate Gray. & Kashmir RockAgama & Least Concern \\
Elapidae & Naja oxiana Eichwald. & Caspian Cobra & Data Deficient \\
Scincidae & Eutropis macularia Blyth. & Bronze Grass Skink & Least Concern \\
& Asymblepharus himalayanus Gunther. & Himalayan Ground Skink & Vulnerable \\
\hline
\end{tabular}

In this study, few reptiles were also sampled which utilized different habitats having vertical vegetation structure, such as; shrubs, trees, and rock crevices for shelter and foraging. It was also found that reptiles often shifted their habitat throughout the day, i.e., early in the morning often utilized rocky sites dominated by shrubs and during midday they moved in to open grassy areas 
(Castilla and Bauwens, 1991) and bedrock substrate for foraging and hideout (Quirt et al., 2006).

The findings of this inventory revealed that vegetation species composition of dry-temperate forest constitute ideal and productive habitat to harbor higher wildlife fauna species to utilize it. Unfortunately, this fragile ecosystem is facing threats due to human interventions, i.e., illegal logging for timber and fuelwood, conversion into agriculture fields along the contours in hilly terrain and human settlements. Hence, it is strongly recommended that this valuable and highly productive habitat should be declared as a protected forest on the priority basis for sustainable use and for future generations.

\section{References}

Ahmad, H., M. Ozturk, W. Ahmad and S.M. Khan: Status of natural resources in the uplands of the Swat Valley, Pakistan. In: Climate Change Impacts on High-Altitude Ecosystems (Eds., M. Ozturk, K.R. Hakeen, I. Faridah, Hanum and R. Efe). Springer Verlag, NY, USA, pp. 49-98 (2015).

Ashraf, N., M. Anwar, I. Hussain and M.A. Nawaz: Competition for food between the markhor and domestic goat in Chitral, Pakistan. Turkish J. Zoology, 38, 191-198 (2014).

Attua, E.M. and O. Pabi: Tree species composition, richness and diversity in the northern forest-savanna ecotone of Ghana. J. App. Biosci., 69, 5437-5448 (2013).

Baboo, B., R. Sagar, S.S. Bargali and H. Verma: Tree species composition, regeneration and diversity of an Indian dry tropical forest protected area. Trop. Ecol., 58, 409-423 (2017).

Bagchi, S., S.P. Goyal and K. Sankar: Prey abundance and prey selection by tigers (Panthera tigris) in a semi-arid, dry deciduous forest in western India. J. Zool., 260, 285-290 (2003).

Balbontin, J., J.J. Negro, J.H. Sarasola, J.J. Ferrero and D. Rivera: Landuse changes may explain the recent range expansion of the black-winged kite Elanus careuleus in Southern Europe. IBIS, 150, 707-716 (2008).

Bauer, S. and B.J. Hoye: Migratory animals couple biodiversity and ecosystem functioning worldwide. Science, 344, 1242552 (2014).

Boldreghini, P. and A. Dall'Alpi: Measuring the abundance and diversity of a waterbird community: Numbers or biomass. Revista Catalana d'Ornitologia, 24, 79-87 (2008).

Carlo, T.A., D. Gracia, D. Martinez, J.M. Gleditsch and J.M. Morales: Where do seeds go when they go far? Distance and directional of avian seed dispersal in heterogeneous landscape. Ecology, 94, 301-3017 (2013).

Castilla, A.M. and D. Bauwens: Thermal biology, microhabitat selection, and conservation of the insular lizard Podarics hispanica atrata. Oceolgia, 85, 366-374 (1991).

Chaves, Ó.M., K.E. Stoner and V. Arroyo-Rodríguez: Differences in diet between spider monkey groups living in forest fragments and continuous forest in Mexico. Biotropica, 44, 105-113 (2012).

Clark, C.J., J.R. Poulsen, R. Malonga and P.W. Elkan: Logging concessions can extend the conservation estate for Central African tropical forests. Conser. Biol., 23, 1281-1293 (2009).

Cristobal-Azkarate, J. and V.A. Rodriguez: Diet and activity pattern of howler monkeys (Alouatta palliata) in Los Tuxtlas, Mexico: Effects of habitat fragmentation and implications for conservation. Amer.
J. Primat., 69, 1013-1029 (2007).

Dale, S. and N. Manceau: Habitat selection of two locally sympatric species of Emberiza Buntings (E. citronella and E. hortulana). J. Ornithol., 144, 58-68 (2003).

Dawson, D.K. and M.G. Efford: Bird population density estimated from acoustic signals. J. App. Ecol., 46, 1201-1209 (2009).

DeFries, R., A. Hansen, A.C. Newton and M.C. Hansen: Increasing isolation of protected areas in tropical forests over the past twenty years. Ecolog. Applic., 15, 19-26 (2005).

Donald, P.F., R.E. Green and M.F. Heath: Agricultural intensification and the collapse of Europe's farmland bird populations. Proc. R. Soc. Lond. B., 268, 25-29 (2001).

Douglas, D.J.T., D. Nalwanga, R. Katebaka, P.W. Atkinson, D.E. Pomeroy, D. Nkuutu and J.A. Vickery: The importance of native tree for forest bird conservation in tropical farmland. Animal Conser., 17, 256-264 (2014).

Edwards, D.P., T.H. Larsen, T.D.S. Docherty, F.A. Ansell, W.W. Hsu, M.A. Derhé, K.C. Hamer and D.S. Wilcove: Degraded lands worth protecting: The biological importance of Southeast Asia's repeatedly logged forests. Proc. Roy. Soc. B., 278, 82-90 (2011).

Fernandez-Alaez, M., C. Fernandez-Alaez and S. Rodriguez: Seasonal changes in biomass of charophytes in shallow lakes in the northwest of Spain. Aquat. Bot., 72, 335-348 (2002).

Fitzeherbert, E.B., M.J. Struebig, A. Morel, F. Danielsen, C.A. Bruhl, P.F. Donald and B. Phalan: How will oil palm expansion affect biodiversity? Trends Ecol. Evolut., 23, 538-545 (2008).

Frickle, E.C., M.J. Simon, K.M. Reagan, D.J. Levey, J.A. Riffell, T.A. Carlo and J.J. Tewksbury: When condition trumps location: Seed consumption by fruit-eating birds removes pathogens and predator attractants. Ecol. Lett., 16, 1031-1036 (2013).

Gonzalez-Zamora, A., V. Arroyo-Rodriguez, O.M. Chaves, S. SanchezLopez, K.E. Stoner and P. Riba-Hernandez: Diet of spider monkeys (Ateles geoffroyi) in Mesoamerica: Current knowledge and future directions. Amer. J. Primatol., 71, 8-20 (2009).

Greenberg, C.H. and S.T. Walter: Fleshy fruits removal and nutritional composition of winter fruiting plants: A comparison of non-native invasive and native species. Nat. Areas J., 30, 312-321 (2010).

Hamel, N.J., A.E. Burger, K. Charleton, P. Davidson, S. Lee, D.F. Bertram and J.K. Parrish: Bycatch and beached birds: Assessing mortality impacts in coastal net fisheries using marine bird stranding. Mar. Ornithol., 37, 41-60 (2009).

Hassen-Aboushiba, A.B., R. Ramli and M. Sofian-Azirun: Ecological characteristics of POME ponds with reference to study some of their invertebrate species in Peninsular Malaysia. J. Ani. Plant Sci., 23, 1305-1315 (2013).

Henderson, P.A. and R.M.H. Seaby: Community Analysis Package 4.0. Pisces Conservation Ltd., Lymington, UK (2007).

Höbinger, T., S. Schindler, B.S. Seaman, T. Wrbka and A. Weissenhofer: Impact of oil palm plantations on the structure of the agroforestry mosaic of La Gamba, southern Costa Rica: Potential implications for biodiversity. Agrofor. Syst., 85, 367-381 (2012).

Homan, H.J., G.M. Linz and W.J. Bleier: Winter habitat use and survival of Ring-necked pheasant (Phasianus colchicus) in southern North Dakota. Amer. Midl. Natur., 143, 463-480 (2000).

Hudon, C.: Impact of water level fluctuations on St. Lawrence River aquatic vegetation. Can. J. Fish. Aquat. Sci., 54, 2853-2865 (1997).

lamsiri, A.: Variables affecting habitat use of Hume's Pheasant in two disturbed sites in northern Thailand. Raffles Bull. Zool., 56, 453456 (2008). 
lamsiri, A. and G.A. Gale: Breeding season habitat use by Hume's Pheasant (Syrmaticus humiae) in the Doi Chiang Dao Wildlife Sanctuary, Northern Thailand. Zool. Study, 47, 138-145 (2008).

Irwin, M.T.: Feeding ecology of Propithecus diadema in forest fragments and continuous forest. Inter. J. Primatol., 29, 95-115 (2008).

Karki, H., K. Bargali, S.S. Bargali and Y.S. Rawat: Plant diversity, regeneration status and standing biomass under varied degree of disturbances in temperate mixed oak-conifer forest, Kumaun Himalaya. Inter. J. Ecol. Environ. Sci., 43, 331-345 (2017).

Khan, B., A. Ablimit, G. Khan, A.W. Jasra, H. Ali, R. Ali, E. Ahmed and M. Ismail: Abundance, distribution and conservation status of Siberian ibex, Marco Polo and Blue sheep in Karakoram-Pamir mountain area. J. King Saud Univer. - Sci., 28, 216-225 (2016).

Kosinski, Z. and P. Tryjanowski: Habitat selection of breeding seedeating passerines on farmland in Western Poland. Ekologia, 19, 307-316 (2000).

Kunz, T.H., E.B. Arnett, B.M. Cooper, W.P. Erickson, R.P. Larkin, T. Mabee, M.L. Morrison, M.D. Strickland and J.M. Szewczak: Assessing impacts of wind energy development on nocturnally active birds and bats: A guidance document. J. Wildlife Manag., 71, 2449-2486 (2007).

Leif, A.P.: Spatial ecology and habitat selection of breeding male pheasants. Wildlife Soci. Bull., 33, 130-141 (2005).

Li, Z., W. Zhou and N. Li: Habitat selection change of Mrs. Hume Pheasant (Syrmaticus humiae) in Dazhongshan during the year. Zool. Res., 31, 499-508 (2010).

Maas, B., D.D. Putra, M. Waltert, Y. Clough, T. Tscharntke and C.H. Schulze: Six years of habitat modification in a tropical rainforest margin of Indonesia do not affect bird diversity but endemic forest species. Biolo. Conser., 142, 2665-2671 (2009).

Martin, G.R. and T. Piersma: Vision and touch in relation to foraging and predator detection: Insightful contrasts between a plover and a sandpiper. Proc. R. Soc. Lond. B. Biol. Sci., 276, 437-445 (2009).

Martin, G.R. and S.J. Portugal: Difference in foraging ecology determine variation in visual fields in ibises and spoonbills (Threskiornithidae). IBIS, 153, 662-671 (2011).

Mason, C.F. and S.M. Macdonald: Corn Bunting Miliaria calandra populations, landscape and land-use in an arable district of eastern England. Bird Conserv. Int., 10, 169-186 (2000).

Mayaux, P., P. Holmgren, F. Achard, H. Eva, H.J. Stibig and A. Branthomme: Tropical forest cover change in the 1990s and options for future monitoring. Phil. Trans. R. Soc. B., 360, 373-384 (2005).

Menz, M.H.M., P. Mosimann-Kampe and R. Artettaz: Foraging habitat selection in the last Ortolan Bunting Emberiza hortulana population in Switzerland: Final lessons before extinction. Ardea, 97,323-333 (2009).

Miettinen, J., C. Shi and S.C. Liew: Deforestation rates in insular Southeast Asia between 2000 and 2010. Global Change Biol., 17, 2261-2270 (2011).

Mumby, P.J., A.J. Edwards, E.P. Green, C.W. Anderson, A.C. Ellis and C.D. Clark: A visual assessment technique for estimating seagrass standing crop. Aquat. Conserv. Mar. Freshw. Ecosysys., 7, 239251 (1997).

Nagmail, T.: Winter habitat partitioning between Asiatic Ibex and Blue sheep in Ladakh, Northern India. J. Mount. Ecol., 8, 7-13 (2006).

O'Rourke, C.T., M.L. Hall, T. Pitlik and E. Fernandez-Juricic: Hawk eyes I: Diurnal raptors differ in visual fields and degree of eye movement. PLOS ONE, 5, e12802 (2010).

Onaindia, M., I. Dominguez, I. Albizu, C. Garbisu and I. Amezaga: Vegetation diversity and vertical structure as indicators of forest disturbance. For. Ecol. Manag., 195, 341-354 (2004).

Parejo, D., J.M. Aviles, M.G. Forero, D. Rivera and J.M. Casas: Communal roosting and diet of black-winged kite (Elanus careuleus) wintering in southwestern Spain. J. Rapt. Res., 35, 162-164 (2001).

Phillips, S.J., R.P. Anderson and R.E. Schapire: Maximum entropy modelling of species geographical distributions. Ecol. Model., 190, 231-259 (2006).

Potier, S., F. Bonadonna, A. Kelber, G.R. Martin, P.F. Isard, T. Dulaurent and O. Duriez: Visual abilities in two raptors with different ecology. J. Exper. Biol., 219, 2639-2649 (2016).

Quirt, K.C., G. Blouin-Demers, B.J. Howes and S.C. Lougheed: Microhabitat selection of five-lined Skinks in Northern peripheral populations. J. Herpetol., 40, 335-342 (2006).

Rajpar, M.N., M. Zakaria, I. Ozdemir, M. Ozturk and S. Gucel: Avian Assemblages at Paya Indah, Natural Wetland Reserve, Malaysia. Expert Opin. Environ. Biol., 6, 1-10 (2017).

Rajpar, M.N.: Tropical Forests Are An Ideal Habitat for Wide Array of Wildlife Species. In Tropical Forests-New Edition. Intech Open (2018).

Rajpar, M.N. and M. Zakaria: Assessing the effects of logging activities on avian richness and diversity in different aged post-harvested hill dipterocarp tropical rainforest of Malaysia. Amer. J. App. Sci., 11, 1519-1529 (2014).

Roemer, G.W., M.E. Gompper and B.V. Valkenburgh: The ecological role of the mammalian mesocarivore. BioSci., 59, 165-173 (2009).

Serrano, D., J.L. Tella, M.G. Forero and J.A. Donazar: Factors affecting breeding dispersal in the faculatively colonial lesser kestrel: Individual experience vs conspecific cues. J. Amer. Ecol., 70, 568578 (2001).

Sharma, L.N., J.G. Grytnes, I.E. Maren and O.R. Vetaas: Do composition and richness of woody plants vary between gaps and closed canopy patches in subtropical forests? J. Veget. Sci., 27, 11291139 (2016).

Sodhi, N.S., L.P. Koh, R. Clements, T.C. Wanger, J.K. Hill, K.C. Hamer, Y. Clough, T. Tscharntke, M.R.C. Posa and T.M. Lee: Conserving Southeast Asian forest biodiversity in human-modified landscapes. Biol. Conserv., 143, 2375-2384 (2010).

Vibhuti, B.K. and S.S. Bargali: Effects of homegarden size on floristic composition and diversity along an altitudinal gradient in Central Himalaya, India. Curr. Sci., 114, 2494 (2018).

Wilson, D.E. and D.M. Reeder (Eds): Mammal Species of the World: A Taxonomic and Geographic Reference. Third Edition. The Johns Hopkins University Press, Baltimore (2005).

Wright, S.J.: Tropical forests in a changing environment. Tren. Ecol. Evolut., 20, 553-560 (2005). 